\title{
Home as a Critical Value: From Shelter TO HOME IN GEORGIA ${ }^{1}$
}

\author{
Cathrine Brun
}

\begin{abstract}
Providing shelter and housing is a core area of humanitarian assistance for displaced populations. Georgia, a former Soviet republic in the South Caucasus, has experienced displacement since the early 1990s, and housing has proved to be politically contentious and a major concern during the 2o-year displacement crisis. In Georgia, as elsewhere, homemaking takes place during displacement in dwellings that are temporary and not supposed to last. The article explores the conditions that enable such homemaking and discusses what Iris Marion Young terms "home as a critical value." One trial project is used as an example: the building of 42 small houses, termed "block houses," in Kutaisi, Western Georgia, by the Norwegian Refugee Council in 2002 and 2003. The article explores the relationships and homemaking practices in and around the houses that people have developed since that date. Relative to others, the project has been a positive example of how to enable home as a critical value. The article first defines house-as-home and introduces the case explored; it then discusses internal displacement and "durable housing solutions" in Georgia, before turning to explore how shelter, housing, home, and homemaking can be conceptualized in displacement. By engaging with Iris Marion Young's "home as a critical value," the article analyzes how people have adjusted to and adapted the block houses in Kutaisi to understand the relationship between the houses and the homemaking that takes place within and around them. The concluding section discusses how home as a critical value may help to show the importance of identity and social status for housing strategies in protracted displacement.
\end{abstract}

\section{Résumé}

Fournir un lieu d'hébergement et de logement constitue l'un des éléments fondamentaux de l'assistance humanitaire pour personnes déplacées. Située dans le Caucause méridional, l'ancienne république soviétique de Géorgie a subi une crise profonde de déplacement datant du début des années '9o-une crise pendant laquelle, sur une période d'une vingtaine d'années, la question du logement est devenue une préoccupation importante, ainsi qu'une question politique très sensible. En Géorgie, comme ailleurs, le processus d'établir un domicile en situation de déplacement se déroule dans un contexte de logements temporaires et précaires. L'article s'engage à explorer les conditions qui permettent l'établissement des domiciles de ce genre et entreprend une discussion du concept de «domicile comme valeur critique» proposé par Iris Marion Young. Un projet pilote en particulier est cité à titre d'exemple, notamment la construction de 42 maisonnettes surnommées "maisons-bloc» à Kutaisi, en Géorgie occidentale, par le Conseil norvégien pour les réfugiés en 2002 et 2003. L'article étudie les liens que les personnes concernées ont développés à partir de cette époque par rapport à ces maisons et leur environnement, ainsi que les pratiques d'établissement de domicile. Ce projet se démarque, relativement aux autres, comme une actualisation positive $d u$ concept de domicile comme valeur critique. L'article commence par définir l'idée de "maison comme domicile» qui est à la base de ce projet et introduit le cas particulier dont il est question. Il aborde ensuite une discussion $d u$ déplacement interne ainsi que les soi-disant "solutions de logement durables» en Géorgie, avant de se pencher sur 
la façon dont les notions de "lieu d'hébergement", "logement», "domicile», et "le processus d'établir un domicile» pourraient être conceptualisés dans des situations de déplacement. En dialoguant avec l'idée d'Iris Marion Young de "domicile comme valeur critique», l'article analyse comment les personnes impliquées dans le projet ont adapté et se sont assimilés aux maisons-bloc à Kutaisi, afin de comprendre le lien entre les maisons et le processus d'établir un domicile qui se développe à la fois dans l'intériorité subjective de ces personnes ainsi que dans leur environnement externe. Pour conclure, la dernière partie démontre comment l'idée de "domicile comme valeur critique" pourrait souligner l'importance de l'identité et du statut social dans le contexte des stratégies sur le logement en situation de déplacement prolongé.

\section{Introduction: From Collective Centres to Block Houses In Kutaisi, West Georgia}

A house-the material structure built for human habitation-is not automatically a home. Houses may be turned into homes by their residents, but some houses will never feel like home-never become home. An interplay of material qualities, symbolic meanings, the occupants' experiences, and their relations with the surroundings of the house may all play a role in enabling a house to become a home. For many people displaced by war, home is believed to be somewhere other than the place of refuge, the place and dwelling they fled from. Displacement from conflict instigates a feeling of loss of home, and making a home at the place of refuge may not be in everyone's interest. The material conditions, the location or social setting of the place of refuge may not be somewhere one would want to call home. Consequently, home may feel irrelevant at the place of displacement, but in this article, I argue that engaging with and including ideas and values of "home" in the humanitarian discourse and practices of providing shelter and housing for long-term displacement may lead to new ways of thinking and practising assistance to internally displaced populations. With Iris Marion Young, ${ }^{2}$ I argue for the introduction of "home as a critical value," a set of minimum standards for fulfilling values of home that should be in place when shelter is provided for populations in situations of unending displacement.

The article has come out of a long-term engagement with displacement in Georgia in the South Caucasus. In July 2003, I visited Kutaisi in Western Georgia as part of an evaluation of shelter projects implemented by the Norwegian Refugee Council (NRC) for internally displaced persons (IDPs) displaced from Abkhazia in the early 1990s. ${ }^{3}$ I was expected to contribute insight into how the organization could develop sustainable housing solutions in a protracted displacement setting where the authorities and displaced alike were unwilling to accept any solution other than return. The main body of the NRC's shelter work was to make the conditions for people more bearable and more dignified by renovating temporary shelters in "collective centres"-buildings such as student and worker dormitories, hospitals, kindergartens, and hotels that were not meant for permanent living and not for family lives. As part of the evaluation, an additional task was to assess a trial project: the building of 42 small houses or cottages-termed "block houses" by the local NRC staff, referring to the simple shape of the houses. The organization had been granted permission by the authorities to build the houses and move families from dire conditions in the collective centres to these houses. The project was contested, because conditions were so much better than in the collective centres and because the houses indicated more permanency than the domestic spaces in the collective centres. The NRC therefore built houses of relatively low quality that were meant to resemble emergency shelters, materials were relatively cheap, walls and windows thin and simple. However, the houses represented more privacy, autonomy, and even livelihoods opportunities with the surrounding gardens where people could grow vegetables.

The IDP category is a highly politicized category frequently used by Georgian authorities for continued claims on Abkhaz territory. The Georgian authorities had reluctantly agreed to the NRC's housing project. IDPs were not supposed to be given permanent houses. Providing IDPs with more permanent housing solutions would give the impression of less willingness and likelihood for return and consequently less power behind continued territorial claims on Abkhazia. IDPs from Abkhazia were thus kept in makeshift buildings in temporary shelters nurturing a hope to return to their homes. The block houses and the collective centres were both considered temporary dwellings.

The first 14 houses were ready in 2002. When I visited in July 2003 the remaining 28 houses were being built. I interviewed the residents after a few months of inhabiting the block houses. People were happy they had moved out of the collective centres and into houses that represented a different life. In September 2010, I came back to the same community. All 42 houses were completed and most were permanently inhabited. In the meantime, policies had changed, and in 2009 the houses were privatized under the provisions of a new state strategy for internally displaced persons. The residents-maintaining the status as IDPsnow owned their houses. I was struck by the major changes that had taken place in the seven years between my first and second visits (see figure 1). On the barren stony land, people had managed to transform the area from an IDPsettlement to a "local" neighbourhood with limited trace of 

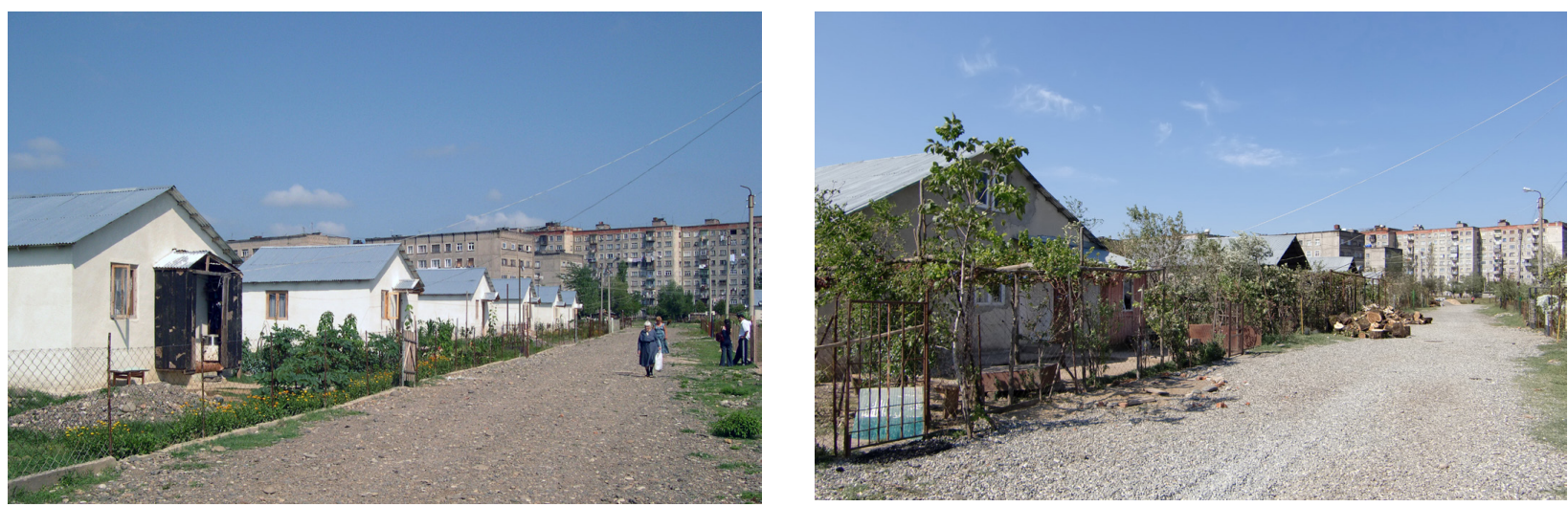

Figure 1: Block houses in Kutaisi, July 2003 and October 2010. Photo @ by author.

the standardized houses and plots that had been provided by the NRC.

During two periods of fieldwork in 2010 and 2012 I conducted more extensive research on housing and home among IDPs in Georgia. I spent time in the settlement to explore the role of the block houses for notions of home and people's perspectives on return and local integration. I interviewed several residents in their houses and gardens, and interviews with one resident often developed into conversations with other people who were visiting from neighbouring houses in the settlement. A majority of the interviewees were women, because men were often out working or searching for employment. However, sometimes the interviews were with husband and wife together. All interviews were conducted with an interpreter, who translated between English and Georgian. The conversations helped to explore further the relationships between shelter, housing, house, and home in a situation of protracted displacement.

"Home" is a multi-scalar phenomenon: it can be a dwelling, a community, and a nation. Each of those scales, such as the dwelling, cannot be understood in isolation, but may be an articulation of a number of social relations at different larger and smaller scales that shape the meaning of that particular dwelling. In this article, the focus is on home in relation to the dwelling, and particularly the role that the material structure of the dwelling plays in displacement and homemaking. While a number of studies on displacement conceptualize the home and focus on the different ways in which home can be understood in different contexts, ${ }^{4}$ and in the Georgian context in particular, 5 I am here concerned with what normative values of home can be considered in housing strategies in protracted displacement. I analyze the symbolic and the practical meaning of the dwelling and how this dwelling enables home through the practices of everyday lives, the making of community, and changing identities during displacement. I engage with discussions about the role of the material dwelling for the experience of home and particularly Young's ${ }^{6}$ proposal of "home as a critical value" to understand the process from shelter to housing in displacement. I explore how engaging with home as a critical value may enable the inclusion of minimum standards of home in housing strategies in protracted displacement: what is the role of the material house in this process, and how can home as a value be seen as part of the way housing is conceptualized in protracted displacement?

In order to discuss how the block houses in Kutaisi have been helpful for understanding home as a critical value, I first discuss the case of internal displacement in Georgia before moving to discuss how shelter, housing, home, and homemaking can be conceptualized in displacement. By engaging with Iris Marion Young's home as a critical value, I then analyze how people adjusted to and adjusted the block houses in Kutaisi and how the houses did and did not enable homemaking and home as a critical value. The concluding section discusses how home as a critical value may help to show the importance of identity and social status for housing strategies in protracted displacement.

\section{Internal Displacement In Georgia: From Temporary Integration to Durable Housing Solutions}

The dissolution of the Soviet Union resulted in the establishment of Georgia as a nation-state and the announcement soon after by Abkhazia of independence from Georgia in 1992. The Georgian authorities did not accept the secession, and Georgian forces entered Abkhazia to regain the territory. The ethnic Georgian population, which consisted of approximately 46 per cent of the pre-war population, fled Abkhazia following the defeat of Georgian forces. The conflict left an estimated 10,000 people dead and some 250,000 
displaced, 7 most of whom continue to be displaced 20 years later.

The Georgians who left Abkhazia settled in different locations in Western Georgia and in and around the capital Tbilisi. They are recognized as internally displaced people (IDPs) by the Georgian government, but, as mentioned above, the IDP category has been highly politicized and used in the conflict between Georgia and Abkhazia. Since displacement, the IDPs and the government have shared a strong concern to return. ${ }^{8}$ The discourse of return to Abkhazia remains prominent, even after the 2008 war, leaving Georgia with an effective loss of control over Abkhazia. The hope for return has created a strong feeling of temporariness that shapes people's conceptions of home as the place they left. At the same time, their temporary status has helped to legitimate substandard shelter during displacement. After 20 years of displacement, the IDPs from Abkhazia remain marginalized in the Georgian society. They have lower employment rates than the general population, they lead more segregated lives, and their housing is believed to be at a lower standard than for the general population. 9 Shelter and housing have been and continue to be major challenges and closely connected to possible solutions to their displacement.

In 2003, when I first came to Georgia, the government, the IDPs, and host populations alike shared the view that the only acceptable solution to the displacement crisis was return. "Local integration" was not a recognized strategy, although some organizations had started to launch the idea of "temporary integration" in informal conversations with government officials. The idea was that displaced people could no longer be kept in the dire housing conditions. Some measures had to be taken to improve their lives, and the new government that came in after the 2003 Rose Revolution gradually relaxed their stance on return. The government strategy for IDPs adopted in 2007 and implemented from 2009, introduced a new term: durable housing solutions. While formulated largely before the 2008 war, implementation of the state strategy on internal displacement gained momentum after the 2008 war, aided by fresh international funds for assisting the new wave of displacement from South Ossetia. Housing is the main focus of the state strategy, and families who were unable to return during the 2008 war were quickly settled in small houses. The houses were similar to the block houses in Kutaisi, and the government built nearly 4,00o cottages in 13 settlements between October and December 2008. The settlements were located outside towns and cities and nearer to South Ossetia. ${ }^{10}$ Policies for what has been termed "old" and "new" IDPs differ somewhat, and for the IDPs from Abkhazia, the state strategy has focused on privatization of living spaces in the collective centres. ${ }^{11}$ At later stages it is anticipated that assistance will be offered to those in rented accommodation and those who already owned their residence in 2007.

People do maintain their IDP status after privatization, and the discourse of return remains strong and influences how IDPs are assisted as well as the quality of housing provided. ${ }^{12}$ Before privatization it was believed that approximately half of the IDP population originating from Abkhazia lived in collective centres, while the other half lived in rented accommodation. ${ }^{13}$ Many of the collective centres were already in bad shape and in need of renovation in the early 1990s when the IDPs moved in with shared bathroom facilities, limited space, and limited privacy. Collective centres are stigmatized and segregated spaces where people live with constant reminders of their plight as IDPs, but the social environment in the buildings is more positive: there is often a close-knit community, a sense of solidarity, and mutual support among the residents.

The current housing strategy provides people living in temporary dwellings with more stability. However, the strategy does not solve the profound inequalities between IDPs and the non-IDPs, and many people's living spaces are hard to improve as a result of the material conditions and the cramped space. Campaigns such as "Housing is more than a roof" by organizations in Georgia have focused on making the government realize that a house may not in itself solve all the problems of displacement and may not create a durable solution on its own. ${ }^{14} \mathrm{~A}$ major problem with privatization and emphasis on housing in general is that the accommodation offered may not be good enough, and that housing is considered very much in isolation from other spheres of life. It is in this context that I analyze one project of housing for IDPs from Abkhazia that I have followed since 2003. First, however, I shall conceptualize shelter, housing, home, and homemaking to suggest how these dimensions may come together in housing strategies in situations of protracted displacement.

\section{Shelter-Housing-Home in Protracted Displacement}

The category of IDPs is extremely important but also profoundly problematic-important because it has helped to recognize the injustice and violation of millions of people worldwide forced to leave their homes and in need of protection and assistance. IDPs are uprooted within their countries of origin, but often without sufficient protection from the state that is supposed, but may be unwilling, to protect them. At the same time, the IDP category is problematic because the state may be using the category and the people labelled IDPs politically to maintain claims on a territory or keep people under control in different ways. The IDP category is a humanitarian category that has implications for 
the kind of shelter to which people have access during displacement. There are minimum standards available, ${ }^{15}$ and the emphasis is on survival, security, personal safety, protection from the environment, and healthy surroundings. IDPs are often assigned to shelters that make people survive, but that cannot be transformed into homes-they are shelters representing the interstices in displaced people's lives; no one is expected to stay there long, but rather to return home or move on. ${ }^{16}$

A humanitarian category is not meant to last, but internal displacement is more often than not protracted. Considering cases of internal displacement that have taken place globally over the past 20 years, the Internal Displacement Monitoring Centre ${ }^{17}$ estimates that only 25 per cent of those displaced during this period have been able return to their homes. Despite this knowledge, short-term humanitarian standards are used but often maintained over 5,10 , or even more than 20 years. More emphasis must be placed on the right to adequate housing and security of tenure in protracted displacement. ${ }^{18}$ "Tenure security" is different from the right to property ownership and includes the full spectrum of tenure forms such as "rental accommodation, co-operative housing, lease, owner-occupation, emergency, housing and informal settlements, including occupation of land or property."'19 Denial of security of tenure denotes denial of the right to acquire property or the restricted ability to repair, improve, or remain in a dwelling established during displacement. Such denial may be a strategy applied by authorities to prevent local integration and more permanency during displacement, and it is often a political strategy to maintain claims on territories, as in the case of Georgia.

A move away from temporary shelter to more permanent housing solutions requires a change from humanitarian minimum standards meant for temporary dwelling to standards for permanent living. Shifting from humanitarian shelter to adequate housing is thus a crucial step in enabling better lives during protracted displacement. As shown in this article, housing and durable solutions have been given particular meanings in the discourse and practices of dealing with displacement in Georgia. It is thus important to unpack the meaning of housing and house in the context of displacement. I would suggest, however, to move one step further to include notions of "home" in housing for protracted displacement. Wilford, ${ }^{20}$ analyzing housing and materiality in the aftermath of Hurricane Katrina, suggests that "housing" may serve as a middle ground between "home" and bare "shelter': "Its relation of kind to 'house' is obviously not stable, but in its usage surrounding Hurricane Katrina it served exactly as a sign for a temporary dwelling that aspired to more than bare shelter but intentionally avoided becoming home." When the block houses in Kutaisi were built, the NRC aspired to provide housing, but avoided making homes. But, as I show below, the block houses enabled homemaking. Housing in protracted displacement must, as I argue here, include the possibility of homemaking, and it must entail an idea of home. I consider the links between housing, house, and home to be the opportunity to make home.

\section{House and Home: Homemaking and Home as a Critical Value}

Home is a powerful ideal embedded within the immediate context of people's lived realities, their past experiences, and present lives. ${ }^{21}$ Iris Marion Young's starting point derives from a feminist critique of home, which led to the rejection of the ideal home by writers such as Luce Irigaray and Simone de Beauvoir. The critique is exemplified by discussing Martin Heidegger's ${ }^{22}$ essay on building and dwelling, with an emphasis on the role of dwelling as constructing. House and home as constructing, the feminist critique argued, comes at women's expense because the reproductive and caretaking role of women in the home to preserve and cultivate the home is not acknowledged and thus deprives women of their own identity and projects. In a patriarchal understanding of home, women become only construction material and caretakers: they become the home. In the feminist critique of the idea of home, there is an analogy to protracted displacement. Simone de Beauvoir, ${ }^{23}$ for example, points to the relationship between social status and relationships to the future. In The Second Sex, the status addressed is that of women in society. She aims to show the oppressive nature of reproductive work, distinguishing between "transcendence" and "immanence." Transcendence refers to the expression of individual subjectivity, expressing a mode of temporality in that the living subject is future oriented: "the future is open with possibility." ${ }^{24}$ In contrast, immanence expresses the movement of life rather than history. It is less oriented to the individual, and more to sustaining life, supporting the transcending individual activities of others, and it is repetitive and cyclical. It is "a time with no future and no goals." ${ }^{25}$ When transcendence is not available, individuals are deprived of their opportunity to express individual subjectivity. When people feel trapped in a never-ending present, ${ }^{26}$ such as in many situations of protracted displacement, it may feel meaningless to work to achieve future goals, because that future lies too far ahead. People live with a status that is not supposed to last, and they do not know how long they can stay, when they should move on, or what will happen when the causes of their displacement change.

While Young acknowledges the deeply problematic values often attached to home, she proposes a defence of the idea of home that carries a liberating potential that expresses 
uniquely human values "which can be uncovered by exploring the meaning-making activity most typical of women in domestic work." 27 Home should enable both immanence and transcendence, and homemaking may involve both caretaking and construction. I suggest that this idea of home needs to be included in the way housing in protracted displacement is understood.

Until recently, few studies of conflict-induced displacement focused on migrants' materialized relationships with their world. ${ }^{28}$ This is perhaps because a feature of conflictinduced displacement is the absence of possessions, and thus the focus has been on those few things that people could bring with them during displacement to affirm an identity. ${ }^{29}$ Dudley $^{30}$ argues that focusing on displaced people's relationship with the material enables a greater insight into the fundamentally cultural processes through which refugees actively and creatively seek to make meaning of and a sense of being "at home" during displacement. Dudley ${ }^{31}$ introduces a materiality approach to forced displacement-an approach that seeks to understand the meanings that refugees create and locate between the social and physical worlds in which they now reside. Her conception of "materiality" lies in the "mutually constitutive relationships between people and things: the embodied, sensory experience of the physical world by an equally physical subject, and the multiple influences each may have on the other." The thing-or object-I am concerned with here is not so much the things people fill their houses with, but rather the house itself, and how the house is an enabling structure that provides a facilitating environment for making home. ${ }^{22}$

As I have shown, house and home are deeply ambivalent values, but Young argues that home (in the understanding of house as home) carries a core positive meaning as the material anchor for a sense of agency and a shifting and fluid identity. The material qualities of home can provide a site of dignity and resistance, and I look at how home as a value can be integrated into housing strategies in protracted displacement. Engaging with the idea of home may also involve minimum standards and rights for adequate housing and secure tenure. Young introduces such standards as "critical values" attached to a particular locale as an extension and expression of bodily routines. She suggests four normative values of home that should be thought of as minimally accessible to all people:

1. Safety-everyone needs a place to go to be safe. Ideally, home means a safe place where we can retreat from the dangers and hassles of collective life.

2. Individuation-existence entails having a space of one's own in which we arrange things around us that belong to us, that reflect our identity back to us in the material identity.
3. Privacy-we do not have a place of our own if anyone has access to us.

4. Preservation-safeguarding the meaningful things in which we see the stories of ourselves embodied.

While these values may be contested, as Young is clearly aware, 33 I take her understanding of home as a critical value to indicate the importance of understanding the embodied nature of the human experience with the house-an experience that takes place as a relationship between home and the physical house through homemaking practices of constructing and caretaking. Homemaking represents the dynamics between people and the block houses in Kutaisi; it involves many temporal registers, ${ }^{34}$ from moving in, moving things around in the house, maintaining, caretaking, renovating, and modifying, and consequently it enables both immanence and transcendence.

The dwelling is at the centre of a multitude of social processes and represents a privileged place from where to understand people's embodied and conceptual appropriation of the world. The walls of the house may be understood as a porous membrane that separates the outside from the inside, but at the same time it opens up for a controlled interaction between inside and outside. 35 While safety and privacy are largely covered by the minimum standards of shelter referred to above, the role of individuation and preservation are covered to a lesser degree by current standards for providing shelter and housing for the internally displaced. To enable home as a critical value through houses for the displaced, there is a need to make the house a safe place from where to negotiate identity and social status. ${ }^{36}$ Houses indicate social status, and by integrating home as a critical value in housing, the house potentially enables its residents to have status equal to that of people in the society in which the house is located.

\section{From Shelter to House: Accommodating}

People who were offered a block house in the settlement in 2003 had lived in dire conditions. Most residents came from collective centres and mainly from an old hospital without windows and sanitation. Not everyone who was offered a house in the new settlement accepted the move. Some did not trust that the housing would last, or that the quality would be much better than what they had in the collective centre, and some said they could not face moving again. After displacement from Abkhazia, they had established themselves in the collective centre, and their homemaking practices took place there, they knew their neighbours, and they felt that moving again would be like another displacement.

For those who decided to move, the physical structure and the material character of the block houses influenced how people practised home, how they used the house, adjusted to 

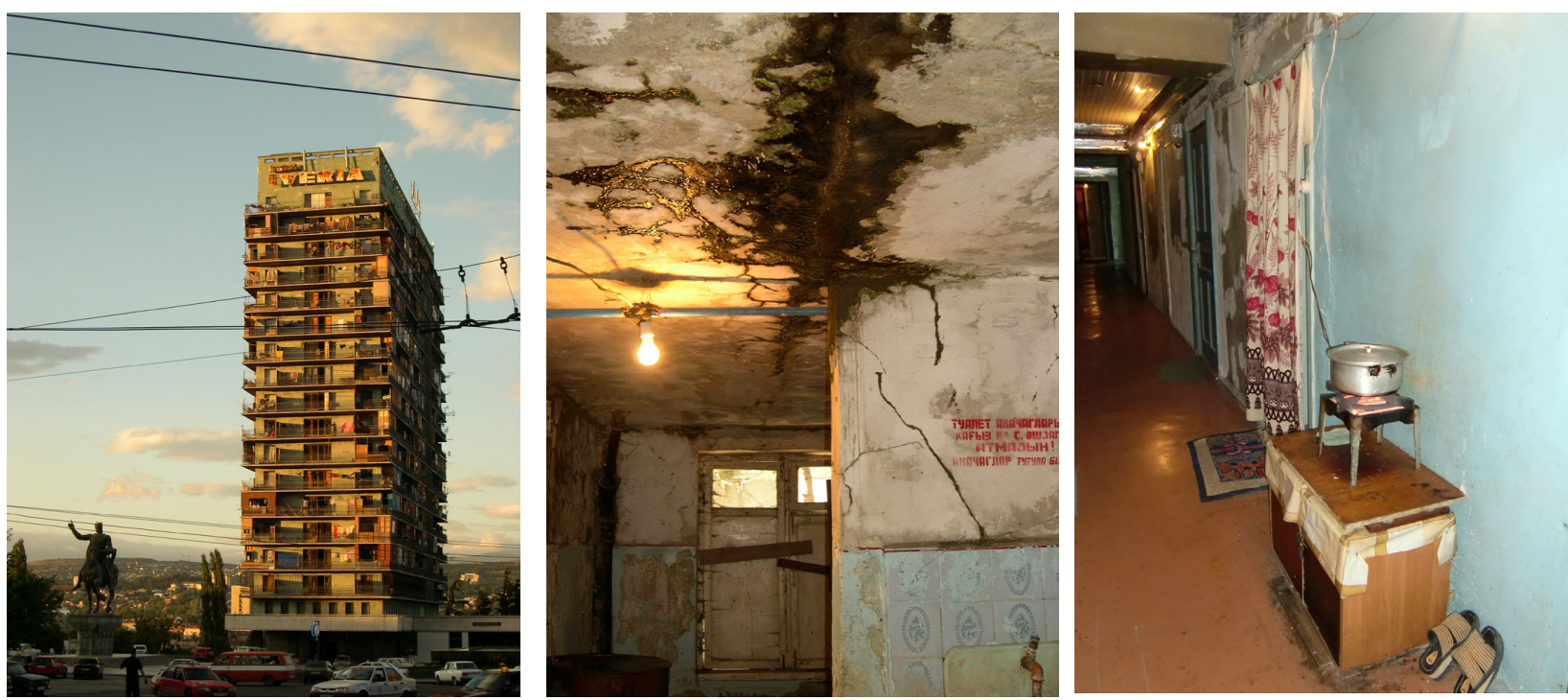

Figure 2: Hotel Iveria (left), the iconic collective centre in Tbilisi in July 2003 (now a Radisson Blue hotel), a communal bathroom in a collective centre (middle), and cooking in the corridor (right). Photo $\odot$ by author.

the house, and adjusted the house in a process that Miller ${ }^{37}$ terms "accommodating." The 42 block houses were all the same size, 36 square metres, the land of each cottage approximately 500 square metres (except for some corner plots that were slightly bigger). Before moving in, many families painted the floors and put wallpaper on the walls. There were two small rooms, a living room, and a bathroom at the back. Some families made a kitchen in one of the two rooms, others made part of the living room into a kitchen. Not many could afford extending the water pipes into the kitchen, but there was water provided to the bathroom. Most people made only cosmetic changes to the houses before moving in, making them beautiful by finding the cheapest wallpaper and floor paint. These acts of decorating and painting contributed to the ways people felt at home in the dwelling. It enabled ways of expressing complex selves-both the biographical and idealized self through homemaking. $3^{8}$

Already in July 2003, when people had lived in the houses for a few months, they had started talking about the alterations and extensions they were planning or wanting to do. The houses enabled making plans for the future and having dreams about things to do at the place of displacement. While their hope for the future was still to return, they could imagine improving their lives during displacement. They were concerned about the limited space of the houses and the low quality, but at the same time happy about being out of the collective centres.

However, even in the context of a strong continued hope for return and feeling of temporality, space was a major concern among the people interviewed. The quality of the houses also represented a worry. They had just lived through the first winter, and walls were thin, windows were of poor quality, and the houses were humid and cold. Still, the physical structure, the location, and the space around the houses enabled homemaking, which took place at many levels, depending on what resources people could mobilize. People were adjusting to the house, but the houses were also seen as an opportunity, and plans for modifications were made.

The block houses enabled stronger connections with the past, in terms of practices of homemaking as well as imagining and recreating feelings of home from the past. In interviews during 2010 and 2012, people recounted the ways in which the house and the surrounding gardens helped to make homes like the ones they had in Abkhazia.

We are taking good care of the house. The land is not too good to cultivate, but we try to make it similar to Abkhazia. We remember how beautiful it was in Abkhazia. From the time we came till the houses became like this, it took some time. All the people who are employed try to make their houses as good as possible. Five or six houses are very good. In the beginning it was very difficultno fences, no roads. During rain it became very muddy—-we had to wear rubber boots. I have worked hard to collect and remove stones to be able to cultivate-now it is good. Then I felt like I was on an island. In the beginning it was hard to breathe here. Now I have made it beautiful. If we had higher ceilings it would be better. But it costs too much money. (Female interviewee, September 2010) 

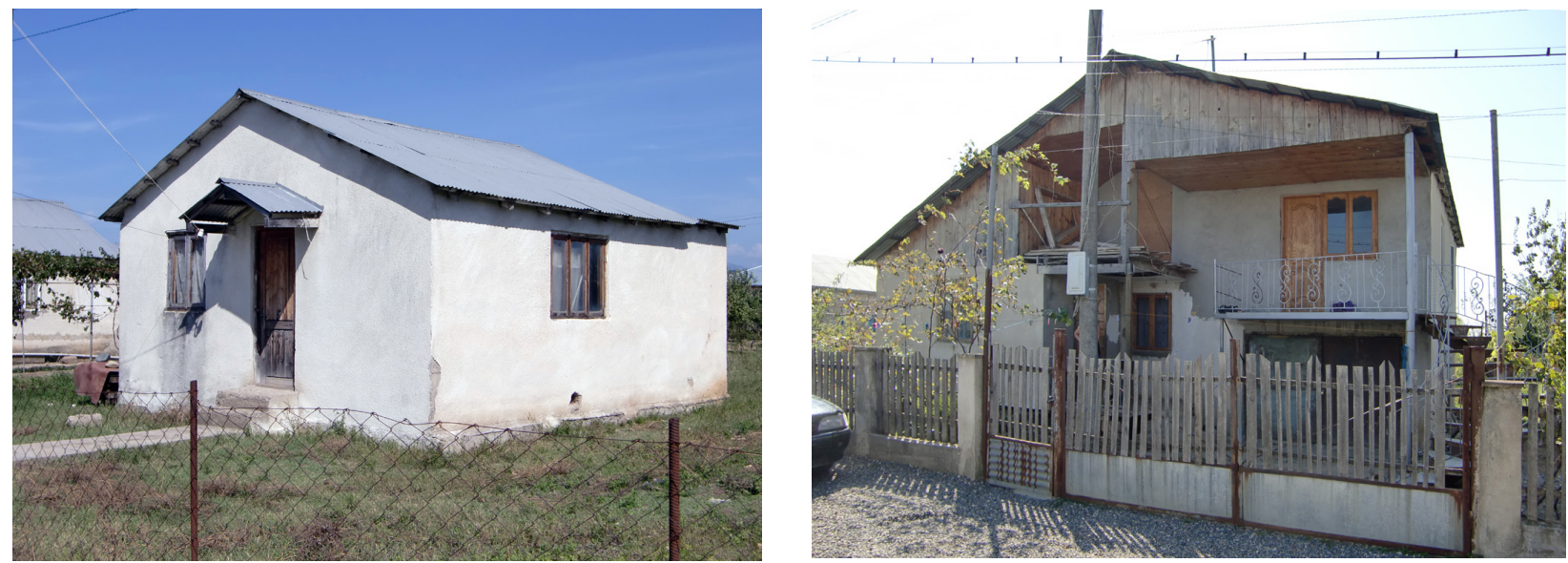

Figure 3: The block house as built in 2003 (left) and an extended house from the original block house in 2010 (right). Photo $\odot$ by author.

With the practices of moving in, establishing a garden, and making the house look nice, people made a place for themselves, a place where they could live, make life, and a home that connected with the memories of a past home. The houses enabled a bearable life and a form of preservation and individuation in displacement. A house may become a generative model for the practice of remembering, 39 an experience prominent in displacement. People made their experiences of displacement meaningful by rendering their dwelling as familiar as possible while seeking to bond to two places and two eras: here and now, and there and then. ${ }^{\circ}$ The houses continue to nurture old and make new memories and to create and recreate identities. Adjusting to and adjusting the house enabled new memories to be embedded in the house. Practising homemaking and making homes have become ways of creating continuity, enable agency and the preservation of identity of subjectivity and a sense of self.

\section{Inside/Outside Relations of House and Home}

Homemaking enabled by the block houses did not take place in isolation from outside events. Important for the accommodating processes between the people and the block houses were the changing context of the conflict and government dealings with the new displaced people from South Ossetia. The 2008 war changed people's hope for return, which affected how people related to the houses. ${ }^{41}$ When privatization started in 2009, hope for return in the near future had changed to hope for return in a distant future. All residents accepted privatization. People decided to privatize because it provided increased autonomy and safety. During their years in the block houses, there were rumours that the houses would be taken over by other interests. Privatization helped to make people feel safer and strengthened the feeling of permanency. Thus, ownership played an important role in homemaking practices. Safety was also maintained gradually before and after privatization and expressed both as social capital and as control over the houses. People had developed a good relationship with neighbouring non-displaced residents, and there was a strong community feeling among the residents in the 42 block houses.

Subsequent to privatization, more residents started investing in their houses. In October 2012, I counted the visible changes that had been made to the exterior of the houses. Of the 42 houses, 14 had no visible alterations, 8 had minor alterations, such as moving the bathroom and building a veranda, 18 had major alterations, which included extending the house to add new rooms and a second floor. Two houses had been demolished and were being rebuilt as bigger houses of better quality. Most people had made alterations in the same sequence: the easiest thing to do and what people had done first was to make a new entrance area and a veranda. The link between the inside-the private-and the surrounding community was established by the veranda-a place from which to look at the passersby and to welcome guests to the house, a defining moment for host and homemaker. Some people then added a bedroom, and 5 households strengthened the foundation and added a second floor. A few households started extending before privatization because they needed the space.

"First we did the veranda. We did not have a plan, we just had to start somewhere. We did it step by step. We had children, both a girl and a boy. They wanted separate rooms, so we started extending. Also for me and my husband [we made a bedroom]. So after the veranda we started to build 
bedrooms. Then we built the bathroom and then the kitchen. Little by little we did it" (female interviewee, October 2012).

Changes made to the houses were determined by people's resources and needs. Most people in the 42 houses had temporary work or were self-employed and found it difficult to generate enough funding to extend the house. When she explained the process of modifying and extending, one house-owner said, "We have extended the house. We used to save on clothes and food, used to eat as little as possible to be able to gradually increase the space. We saved all the money we earned." This family had made a second-floor addition as well as a ground floor extension, and the original structure was no longer recognizable. However, in addition to being successful at saving money, a family member abroad contributed with remittances that were used mainly to extend and improve the house. Another family, who had built one of the biggest houses in the settlement, established themselves with an extensive local network through a religious organization. All the material used to build their house was second-hand material from members of the organization who had also assisted in the building work.

Many who had made major alterations and extensions to their houses had family members or relatives abroad who had helped them to make the changes. Some of those who wanted to make changes could not, as a result of unemployment or under-employment. Some had not extended their houses because their household comprised only one or two persons and they did not need more space. Most people who had made major alterations to their houses were still building. Many of the interviewees said they were tired of living on a building site. However, making changes to the house over time was the only way to improve and extend the houses, because it took time to save the necessary funds. In 2012, most people interviewed, regardless of whether changes had already been made or not, said they were saving money to extend and improve their houses.

Houses were built with materials of poor quality, and in 2012, many things were in need of repair after nearly ten years of occupancy. With privatization, people cannot find assistance to make these repairs. Earlier, they went to the local office of the ministry dealing with internal displacement to ask for assistance, but now, as they owned the houses, they had to go the mayor of Kutaisi to ask for the same assistance as all the other established neighbourhoods and households in the town. In three of the houses I visited where no alterations had been made, there were families with two or three children, and they just could not afford to make improvements. In these cases, the houses were run down, pipes were leaking, and families living in the houses worried about the coming winter. In one case, simple homemaking practices such as cooking took place in the house of the wife's mother, who lived in another block house. This family was looking at the improvements made to other houses and longing for the employment that could make it possible for them to make their house more comfortable.

\section{A Roof Is Not Enough: Marginalization and Inclusion}

"Yes [the house is different from the collective centre], first of all, living conditions: there was a lot of smoke and noise. It is more private. I have my own house. If someone visits me, we can freely talk and discuss. We do not disturb anyone. We have our own garden. We have tomatoes. Almost everyone has tomatoes. We can have fruits and we can add more" (female interviewee, July 2003).

"It is not that we do not want to return. But we feel at home here. We are used to living here. Used to the neighbours-we are used to the transportation system. When we lived in the collective centre, there were always problems" (female interviewee, September 2010).

"No, this house will never be my home" (male interviewee, October 2012).

Home is a deeply ambiguous value and concept to include in discussions about housing for protracted displacement. Even when made available, a house that fulfils minimum standards does not automatically become home. Making a home may not even be the aim for displaced people at the place of displacement, and some inhabitants in the block houses did not feel that they had managed to achieve a home. Even at the same starting point-the same house and a shared history of displacement-the families in the settlement in Kutaisi had different relationships to the houses. Some people developed their lives and some remained in a marginal position as a result of different social, economic, and human capital. However, all residents whom I interviewed agreed that the block houses in Kutaisi enabled homemaking - the houses facilitated what Gregson $4^{2}$ terms "estate agency" to varying degrees and made visible the dwelling as an enabling structure for achieving a set of minimum standards. As mentioned above, looking at the relationship between minimum standards for shelter and home as a critical value, safety and privacy are present in both. However, Young's introduction of individuation and preservation are distinct from housing and requires an understanding of home as a critical value.

Preservation and individuation concern a person's sense of identity and the relationship between the material house and identity; it is about how identity is influenced by the house and how the house may become a materialization of 
identity that makes a continuity between past and present. ${ }^{43}$ The permanency of the dwelling as somewhere to stay in the future, together with the changing materiality of the same dwelling, help to understand the dynamic process and changing and differing identities that people in the block houses experience and practise. The inhabitants of the block houses expressed very different relationships to the houses. In this context, a highly ambiguous dimension in the discussion of homemaking and home as a critical value in the block houses in Kutaisi is the gendered practices of homemaking, which attest to the feminist critique of home mentioned above: men are more involved in the constructing, while women are caretaking and hence associated more with the home that men are building. Despite these gendered practices, men and women in the block houses in Kutaisi considered constructing and caretaking as joint family projects. Together with gender, equally prominent in differentiating how people felt connected to the block houses were their economic and social positions before and after displacement. One family whose house had been extended long before privatization and as such represented one of the most established houses among the 42 block houses were perhaps the most articulate about their house in Kutaisi not being their home (see the last of three quotations above by the male IDP). Where the experience of lost social standing was most prominent after displacement, people tended to long for a future that was located in the past and did not want to feel home at the place of displacement. It was not always the condition of the house and the amount of work that people had put into the house that affected people's understanding of home. The understanding of their own status in Georgian society was perhaps more prominent in understanding the role of the block houses in enabling home as a critical value. Their social status indicated the loss of social standing and what was considered lost future possibilities at the place of displacement.

The block houses influenced the status and social position of the residents, and their experience of social status influenced their relationship to their houses. Young emphasizes individuation as a critical value: a person without a home is quite literally deprived of individual existence. There is a connection between individuation, the status of IDPs, and the symbolic meaning of the IDP dwelling. The collective centre has become a symbol of displacement-of people being out of place. The block houses continue to be termed the "IDP settlement" by neighbouring non-displaced residents, but the 42 block houses seem to have been given a status different from that of the collective centres. The residents of the block houses state that they live in an attractive neighbourhood, and maintain relations with non-displaced as well as displaced. The houses can clearly be seen as tools for human activity, ${ }^{44}$ and the houses have helped to achieve Young's fourth critical value of home as preservation: the activity of safeguarding the meaningful things in which one sees the stories of oneself embodied and rituals of remembrance that reiterate those stories. While many of the people I interviewed had a nostalgic relationship with ideas of home, they dreamed of a home that they lost and could never be regained. The way the block houses enabled preservation is, however, very different from nostalgia. The houses enable homemaking in accordance with how past experiences have taught them what a home should be. They are not recreating Abkhazia; rather, the houses encourage preservation, which offers the possibility of connecting the past in Abkhazia and the future in their houses in Kutaisi.

\section{Home as a Critical Value in Protracted Displacement}

When home as a critical value, as suggested by Iris Marion Young, was fulfilled in the block houses, it was not because of the material structure of the houses alone. However, the material house played together with the location, the garden, and the social, human, and economic capital that the houses enabled to some extent. The block houses made homemaking possible, made people envisage a possible future in the block houses, and facilitated home as a critical value, although individuation, preservation, safety, and privacy were not necessarily achieved by everyone. There are particular power relations, mechanisms, and processes that may help to understand the unequal achievement of the values of home through the block houses.

At the time the block houses in Kutaisi were built, they represented an exceptional example among the housing projects for internally displaced from Abkhazia. Later the houses built for the displaced from South Ossetia in 2008, mentioned above, were built in a similar style. However, some key differences must be emphasized. First, the houses were in larger settlements that hence resembled displaced person's camps, with a higher level of segregation. Additionally, their location, although sometimes close to a village of non-displaced persons, had even fewer opportunities for livelihoods than in towns and cities.

It will not be possible for every IDP in Georgia to have a house and a garden in a central town location. But the case of the block houses in Kutaisi is important, because it shows what the enabling structure of a house can and cannot do. By analyzing this relatively successful story of housing for displaced people in protracted displacement, it is possible to show the importance of shifting from shelter to housing when considering protracted displacement. It is also possible to show that a house is not enough, but that we need to integrate the idea of home into the way we think about the house as a material structure. 
I have suggested that more effort should go into developing a minimum standard for housing in protracted displacement that engages with home, not as a nostalgic idea or as homeland, but house as home-as a safe place from where agency can be pursued, and lives can be lived during displacement.

Including home as a critical value in housing for protracted displacement requires considering the ways in which people's statuses as internally displaced and their position in the societies where they live are understood. So far people have not escaped the humanitarian category of IDP that largely restricts people's inclusion among the non-displaced. The maintenance of subjectivity, identity, and consequently house as home through the block houses, represents a liberating potential. This potential has not been fully achieved, and home may be a problematic idea to include in housing. Although people may or may not want to make the house where they live a home, the possibility of house-as-home should be accessible. Housing in protracted displacement requires housing standards for permanent living where the future is considered possible in that dwelling. As Young says, 45 "Even if people have minimal shelter of their own ..., they need a certain level of material comfort in their home for it to serve as a place of identity construction and the development of the spirit of resistance.... In this way having a home is indeed today having a privilege."

Cathrine Brun is a geographer and teaches at the Department of Geography at the Norwegian University of Science and Technology. Her research concerns protracted displacement and recovery and development after war and disasters. Her main geographical area of research has been South Asia and the South Caucasus.

The author may be contacted at cathrine.brun@svt.ntnu.no.

\section{Notes}

1 The article was first presented as a paper at the 14th International Association for the Study of Forced Migration in Kolkata, India. A special thanks to Anita H. Fabos, Julia Kharasvili, Mariam Naskidashvili, Khatia Kardeva, two anonymous reviewers, and Christina Clark-Kazak for their contributions to fieldwork, writing, and publishing.

2 Iris Marion Young, "House and Home: Feminist Variations on a Theme," in On Female Body Experience: Throwing like a Girl and Other Essays (New York: Oxford University Press, 2005), chap. 7.

3 Norwegian Refugee Council, From Shelter to Housing: Security of Tenure and Integration in Protracted Displacement Settings (n.p.: NORAD/NRC, 2012).
4 Cathrine Brun and Anita Fabos. "Making Homes in Limbo? A Conceptual Framework," this issue.

5 Cathrine Brun, "Home in Temporary Dwellings." In International Encyclopedia of Housing and Home, ed. Susan J. Smith, Marja Elsinga, Lorna Fox O’Mahony, Ong Seow Eng, Susan Wachter, and Robyn Dowling (Oxford: Elsevier, 2012), 424-33; Peter Kabachnik, Joanna Regulska, and Beth Mitchneck. "Where and When Is Home? The Double Displacement of Georgian IDPs from Abkhazia," Journal of Refugee Studies 23, no. 3 (2010): 315-36.

6 Young, "House and Home."

7 Amnesty International, In the Waiting Room: Internally Displaced People in Georgia (London: Amnesty International, 2010).

8 Peter Kabachnik. "Wounds That Won't Heal: Cartographic Anxieties and the Quest for Territorial Integrity in Georgia," Central Asian Survey 31, no. 1 (2012): 45-6o.

9 Magdalena Frichova Grono, Displacement in Georgia: IDP Attitudes to Conflict, Return and Justice-An Analysis of Survey Findings (Tbilisi: Conciliation Resources, 2011); Beth Mitchnek, Olga Mayorova, and Joanna Regulska. "'Post'-Conflict Displacement: Isolation and Integration in Georgia," Annals of the Association of American Geographers 99, no.5 (2009): 1022-32; George Tarkhan-Mouravi, Assessment of IDP Livelihoods in Georgia: Facts and Policies (Tbilisi: Danish Refugee Council, United Nations High Commissioner for Refugees, European Union, 2009).

10 Open Society Georgian Foundation, Cottage Settlements for Georgian IDPs: Accountability in Aid Construction (Tbilisi: Open Society Georgian Foundation, 2010).

11 Interviews, Ministry for IDPs, 2010 and 2012.

12 Kabachnik, "Wounds That Won't Heal."

13 NRC, From Shelter to Housing.

14 Julia Kharashvili and Cathrine Brun, "A Roof Is Not Enough" (Paper presented at the International Association of Forced Migration conference, Kolkata, January 2013).

15 A common set of minimum standards can be found in the Sphere Project, Minimum Standards in Shelter, Settlement and Non-Food Items, http://www.spherehandbook. org/content/pages/en/8.minimum-standards-in-shelter_ settlement-and-non-food-items.pdf.

16 Cathrine Brun, "Active Waiting and Changing Hopes: Toward a Time Perspective on Protracted Displacement," Social Analysis 59, no. 1 (2015): 19-37.

17 Internal Displacement Monitoring Centre, Protracted Internal Displacement in Europe: Current Trends and Ways Forward (Geneva: IDMC / Norwegian Refugee Council, 2009).

18 NRC, From Shelter to Housing.

19 Ibid., 6.

20 Justin Wilford, "Out of the Rubble: Natural Disaster and the Materiality of the House," Environment and Planning D: Society and Space 26, no. 4 (2008): 656. 
21 Cameron Parsell, "Home Is Where the House Is: The Meaning of Home for People Sleeping Rough," Housing Studies 27, no. 2 (2012): 159-73.

22 Martin Heidegger, "Building Dwelling Thinking," in Poetry, Language, Thought, trans. and intro. Albert Hofstadter,1954; New York: Harper \& Row, 1971).

23 Simone de Beauvoir, The Second Sex, trans. H. M. Parshley (London: Pan Books, 1949).

24 Young, "House and Home," 137.

25 Ibid., 138.

26 Craig Jeffrey, "Waiting," guest editorial, Environment and Planning D: Society and Space 26 (2008): 954-58.

27 Young, "House and Home," 124.

28 Sandra Dudley, "Feeling at Home: Producing and Consuming Things in Karenna Refugee Camps on the ThaiBurma Border," Population, Space and Place 17 (2011): 742-55.

29 Deidre Conlon, "A Fractured Mosaic: Encounters with the Everyday amongst Refugee and Asylum Seeker Women," Population, Space and Place 17 (2011): 714-26; David Parkin, "Mementoes as Transitional Objects in Human Displacement," Journal of Material Culture 4, no. 3 (1999): 303-20.

30 Dudley, "Feeling at Home."

31 Ibid., 747.

32 See Zeynep Turan. "Material Objects as Facilitating Environments: The Palestinian Diaspora," Home Cultures 7, no. 1 (2010): 43-58; Martha Nussbaum, Upheavals of Thought: The Intelligence of Emotions (Cambridge: Cambridge University Press, 2001).
33 Alison Weir, "Home and Identity: In Memory of Iris Marion Young," Hypatia 23, no. 3 (2008): 4-21.

34 Nicky Gregson, Living with Things: Ridding, Accommodation, Dwelling (Wantage, UK: Sean Kingston Publishing, 2007).

35 Maria Kaika, "Interrogating the Geographies of the Familiar: Domesticating Nature and Constructing the Autonomy of the Modern Home," International Journal of Urban and Regional Research 28, no. 2 (2004): 265-86.

36 bell hooks, Yearning: Race, Gender, and Cultural Politics (Boston: South End, 1990).

37 Daniel Miller, Stuff (Cambridge: Polity, 2010).

38 Pauline Garvey, "Organized Disorder: Moving Furniture in Norwegian Homes," in Home Possessions: Material Culture behind Closed Doors, ed. Daniel Miller, 47-68 (Oxford: Berg, 2001).

39 Christopher Morton, "Remembering the House: Memory and Materiality in Northern Botswana," Journal of Material Culture 12, no. 2 (2007): 157-79.

40 Dudley, "Feeling at Home."

41 Brun, "Active Waiting and Changing Hopes."

42 Gregson, Living with Things.

43 Young, "House and Home," 141.

44 Pauli Tapani Karjalainen, "House, Home and the Place of Dwelling," Scandinavian Housing and Planning Research 10, no. 2 (1993): 65-74.

45 Young, "House and Home," 151.

(C) Cathrine Brun, 2015. This open-access work is licensed under a Creative Commons Attribution-NonCommercial 4.0 International License, which permits use, reproduction and distribution in any medium for non-commercial purposes, provided the original author(s) are credited and the original publication in Refuge: Canada's Journal on Refugees is cited. 